\title{
Expression of $\mathrm{AT}_{2}$ Receptors in the Developing Rat Fetus
}

\author{
Eileen F. Grady, Leonardo A. Sechi, Chandi A. Griffin, Morris Schambelan, and Judith E. Kalinyak \\ Division of Endocrinology, Department of Medicine, San Francisco General Hospital, \\ University of California, San Francisco, California 94110
}

\begin{abstract}
Angiotensin II is known primarily for its effects on blood pressure and electrolyte homeostasis, but recent studies suggest that angiotensin II may play a role in the regulation of cellular growth. This study was undertaken to identify the angiotensin II receptor subtypes expressed during fetal and neonatal development and to characterize their cellular localization. Using an in situ receptor binding assay on sagittal frozen sections of fetal and neonatal rats, bound ${ }^{125}{ }^{I}-\left[\mathrm{Sar}^{1}\right.$, Ile $\left.^{8}\right]$-angiotensin II was visualized by film and emulsion autoradiography. Bound radioligand was detected by E11 (embryonic day 11) and maximal binding occurred by E19-21. Radioligand binding remained unaltered $30 \mathrm{~min}$ after birth, whereas a noticeable and stable decrease was observed $12 \mathrm{~h}$ postparturition. The highly abundant angiotensin II receptors were shown to be $\mathbf{A T}_{2}$ by the marked reduction in radioligand binding achieved with $\mathrm{PD} 123177\left(10^{-7}\right.$ $M)$, a specific $\mathrm{AT}_{2}$ receptor antagonist, whereas DuP $753\left(10^{-5}\right.$ $M)$, an $\mathrm{AT}_{1}$ receptor antagonist, had little effect. Emulsion autoradiography showed radioligand binding in the undifferentiated mesenchyme of the submucosal layers of the intestine and stomach, connective tissue and choroid surrounding the retina, subdermal mesenchyme adjacent to developing cartilage, diaphragm, and tongue. Residual $\mathrm{AT}_{2}$ receptors were found on the dorsal subdermal region of the tongue $72 \mathrm{~h}$ after birth. $\mathrm{AT}_{1}$ receptors were detected in the placenta at E13 and in the aorta, kidney, lung, liver, and adrenal gland at E19-21, consistent with an adult distribution. The transient expression of $\mathrm{AT}_{2}$ receptors in the mesenchyme of the fetus suggests a role of angiotensin II in fetal development. (J. Clin. Invest. 1991. 88:921933.) Key words: development • DUP 753 • PD1 23177 • mesenchyme • embryogenesis
\end{abstract}

\section{Introduction}

Angiotensin II receptors are present in a wide variety of tissues in the adult vertebrate (1-3). Acting through these receptors, angiotensin II maintains circulatory homeostasis $(4,5)$, stimulates the secretion of prolactin (6), aldosterone (7), adrenocorticotropic hormone (8), and corticotropin releasing hormone

Address correspondence to Judith E. Kalinyak, M.D., Ph.D., Division of Endocrinology, Building 100, Room 286, San Francisco General Hospital, San Francisco, CA 94110. 1991.

Received for publication 24 April 1991 and in revised form 20 June

J. Clin. Invest.

(c) The American Society for Clinical Investigation, Inc. 0021-9738/91/09/0921/13 \$2.00

Volume 88, September 1991, 921-933
(9), acts as a neurotransmitter in the central nervous system (10), and has a less well defined role in the function of reproductive organs $(11,12)$. All the components of the renin-angiotensin system (RAS), ${ }^{1}$ including angiotensin II receptors, have been colocalized within many adult organs $(13,14)$ and in the developing fetal-placental unit $(15,16)$. Because both the renin and angiotensinogen genes $(14,17)$ and angiotensin II receptors $(18,19)$ are regulated in a tissue-specific fashion, it has been suggested that the RAS has autocrine/paracrine functions that may be independent from its function in cardiovascular homeostasis. Angiotensin II is also one of a growing number of peptide hormones that have been implicated in the regulation of cellular growth (20). Angiotensin II potentiates the mitogenic effect of epidermal growth factor (21), increases expression of platelet-derived growth factor (22) and the proto-oncogenes c-fos $(23,24)$, c-myc (22), and c-jun (25). The RAS is active during fetal development and high concentrations of angiotensin II receptors are expressed transiently in mouse, rat, and primate fetuses (26-29).

Two distinct angiotensin II receptor subtypes (AT $_{1}$ and $\mathrm{AT}_{2}$ ) have been identified by both sensitivity to dithiothreitol $(30,31)$ and by their ability to bind the nonpeptide antagonists DuP $753\left(\mathrm{AT}_{1}\right)$ and PD123177 $\left(\mathrm{AT}_{2}\right)(32,33)$. In the adult rat, the majority of the hemodynamic actions of angiotensin II are mediated through the $\mathrm{AT}_{1}$ receptor (33-35). The type and cellular localization of angiotensin II receptors expressed in the developing rat fetus and neonate are not known. This study demonstrates that this highly abundant and transiently expressed angiotensin receptor is $\mathrm{AT}_{2}$ and identifies the cellular sites of expression in the developing fetus and neonate.

\section{Methods}

Animals. Rats were maintained on rat chow and tap water ad lib., with 12-h light/dark cycles. Timed pregnant and neonatal Sprague Dawley rats were killed by carbon dioxide asphyxiation and the fetuses (embryonic day $[E] 11,12,14,16,19,20$, and 21$)$ or neonatal pups $(6,12,24$, 48 , and $72 \mathrm{~h}$ of age) were placed in optimal cutting temperature mounting medium, snap frozen in liquid nitrogen, and stored at $-80^{\circ} \mathrm{C}$ before sectioning. The day after a vaginal plug was observed was considered to be embryonic day 0 .

In situ angiotensin II receptor assay. Angiotensin II receptors were localized using the method of Mendelsohn et al. $(36,37)$. Briefly, midsagittal frozen sections $(4 \mu \mathrm{m})$ of whole fetuses or pups were cut on a cryostat at $-20^{\circ} \mathrm{C}$, thaw-mounted onto poly-L-lysine coated slides, dried in vacuo overnight at $-5^{\circ} \mathrm{C}$ over silica gel, and stored with silica gel in sealed boxes at $-80^{\circ} \mathrm{C}$. Immediately before use, the sections were dried for an additional $2-4 \mathrm{~h}$ in vacuo at room temperature. The endog-

1. Abbreviations used in this paper: E, embryonic day; RAS, renin-angiotensin system; TGF, transforming growth factor. 


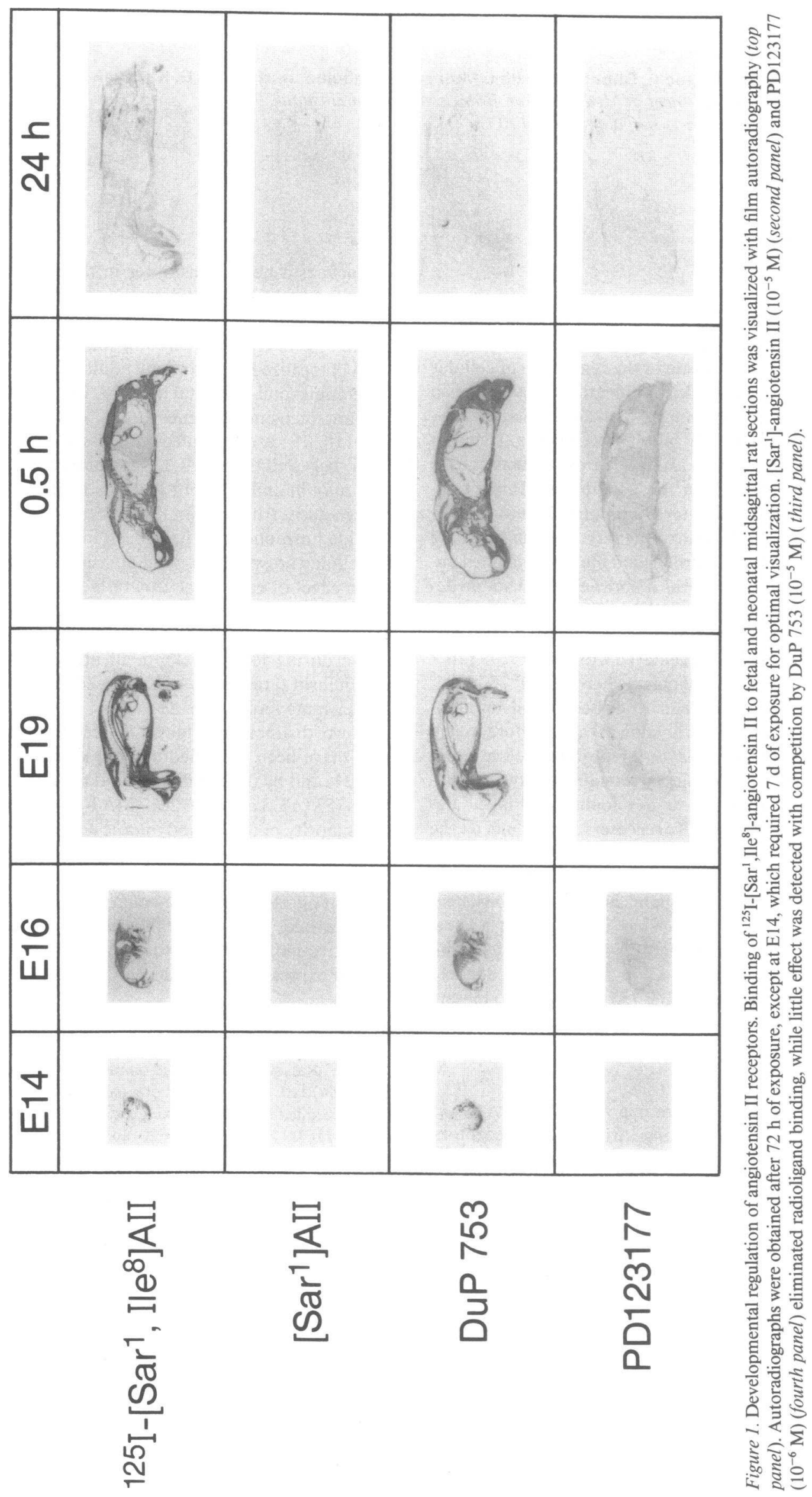



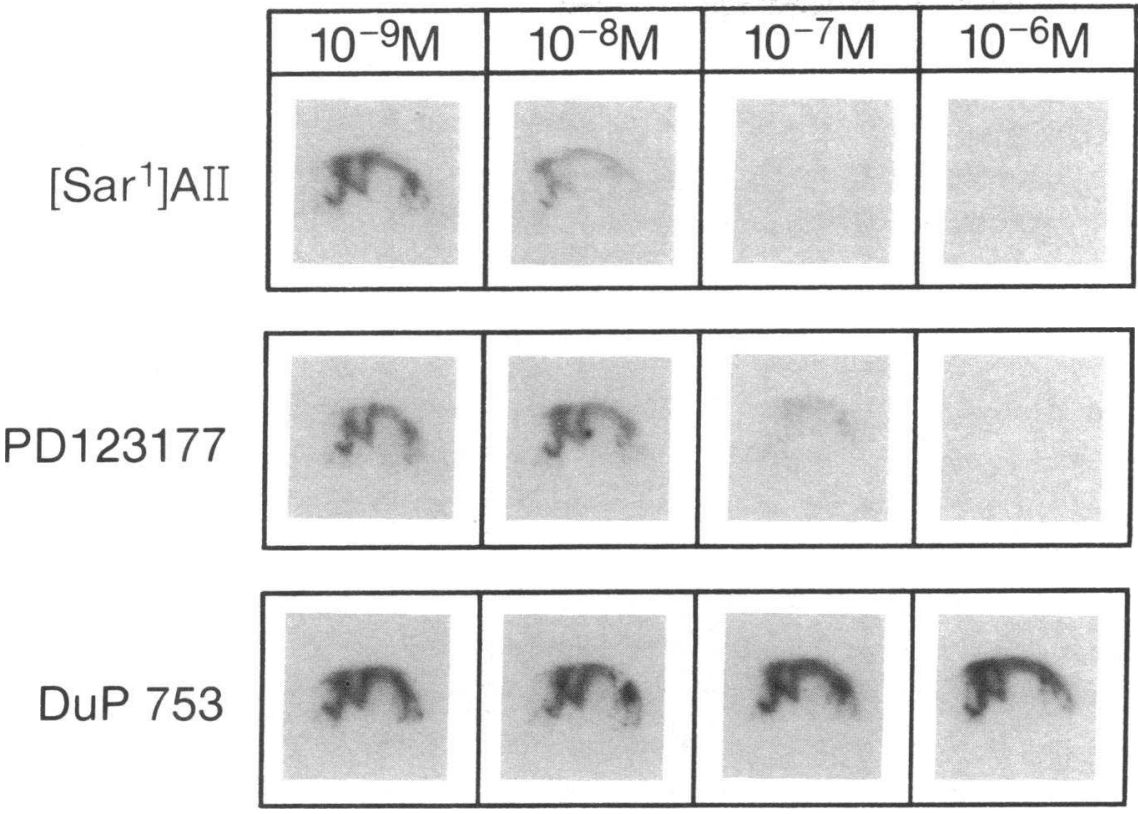

Figure 2. Receptor antagonist competition curves. Using E16 fetal sections, radioligand binding in the presence of increasing concentrations $\left(10^{-10}-10^{-3} \mathrm{M}\right)$ of $\left[\mathrm{Sar}^{1}\right]$-angiotensin II, (top panel), PD123177, (middle panel), and DuP 753, (bottom panel), was visualized by film autoradiography in three separate experiments. Depicted above is a representative autoradiograph showing the concentrations of PD123177 and [Sar ${ }^{1}$ ]-angiotensin II necessary to achieve maximal radioligand inhibition. DuP 753 at $10^{-4} \mathrm{M}$ was necessary to achieve any visible binding inhibition. enously bound ligand was removed by preincubation with $10 \mathrm{mM}$ sodium phosphate buffer, pH 7.4, containing $150 \mathrm{mM} \mathrm{NaCl}, 5 \mathrm{mM}$ $\mathrm{Na}_{2}$ EDTA, $0.3 \mathrm{mM}$ bacitracin, and $0.2 \%$ BSA for $20 \mathrm{~min}$ at room temperature. This was replaced with the same buffer containing 250 pM ${ }^{125}{ }_{\mathrm{I}}$-[Sar $\left.{ }^{1}, \mathrm{Ile}^{8}\right]$-angiotensin II $(2,200 \mathrm{Ci} / \mathrm{mmol}$, DuPont NEN Research Products, Boston, MA) and the sections were incubated for 60 min at $16^{\circ} \mathrm{C}$ in a humidified chamber. Sections were washed four times

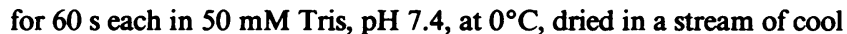
air, and exposed to Ultrofilm (Reichert-Jung, Heidelberg, Germany) for 4-14 d. The receptor-angiotensin II complexes were fixed by exposure to paraformaldehyde vapors at $80^{\circ} \mathrm{C}$ for $2 \mathrm{~h}$ in a closed chamber under vacuum. The vapors were evacuated from the chamber and the sections left under a drafted hood overnight to ensure removal of residual vapors. The sections were subsequently coated with NTB2 photographic emulsion (Eastman Kodak Co., Rochester, NY) and air dried lying flat $(37,38)$. The sections were exposed for $4-8 \mathrm{~d}$ at $4^{\circ} \mathrm{C}$, stained with hematoxylin-eosin, and examined by bright/dark-field microscopy using a Zeiss Universal microscope equipped with a dark-field condenser. Routine controls to evaluate the emulsion for altered chemography included coating a blank slide (to detect background levels of silver grains in the emulsion) and coating sections which had no radioligand in the receptor binding buffer. In addition, specificity of

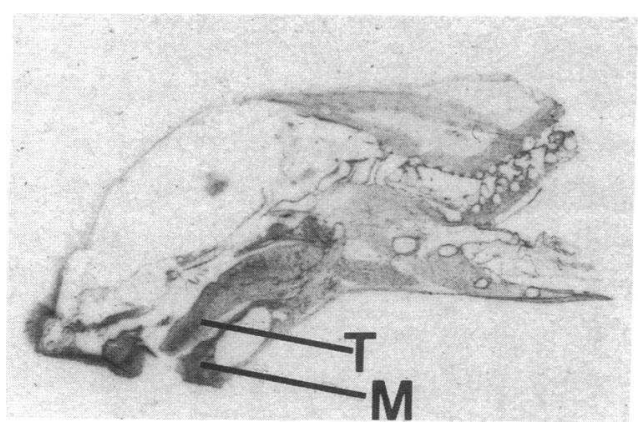

Figure 3. Angiotensin II radioligand binding in the head of a rat $72 \mathrm{~h}$ after birth. An autoradiograph of radioligand binding to midsagittal frozen sections obtained $72 \mathrm{~h}$ postparturition reveals residual binding to $\mathrm{AT}_{2}$ receptors in the tongue $(T)$ and lower mandible $(M)$. binding was evaluated with [Sar $\left.{ }^{1}\right]$-angiotensin II $\left(10^{-5} \mathrm{M}\right)$ (Peninsula Laboratories, Inc., Belmont, CA) while receptor subtypes were identified by inhibition of radioligand binding with the receptor antagonists DuP $753\left(10^{-5} \mathrm{M}, \mathrm{AT}_{1}\right)$ and PD123177 $\left(10^{-6} \mathrm{M}, \mathrm{AT}_{2}\right)$, generously provided by E. I. du Pont de Nemours \& Co., Wilmington, DE. Each experiment was repeated a minimum of three times with highly reproducible results. The autoradiographs presented are representative.
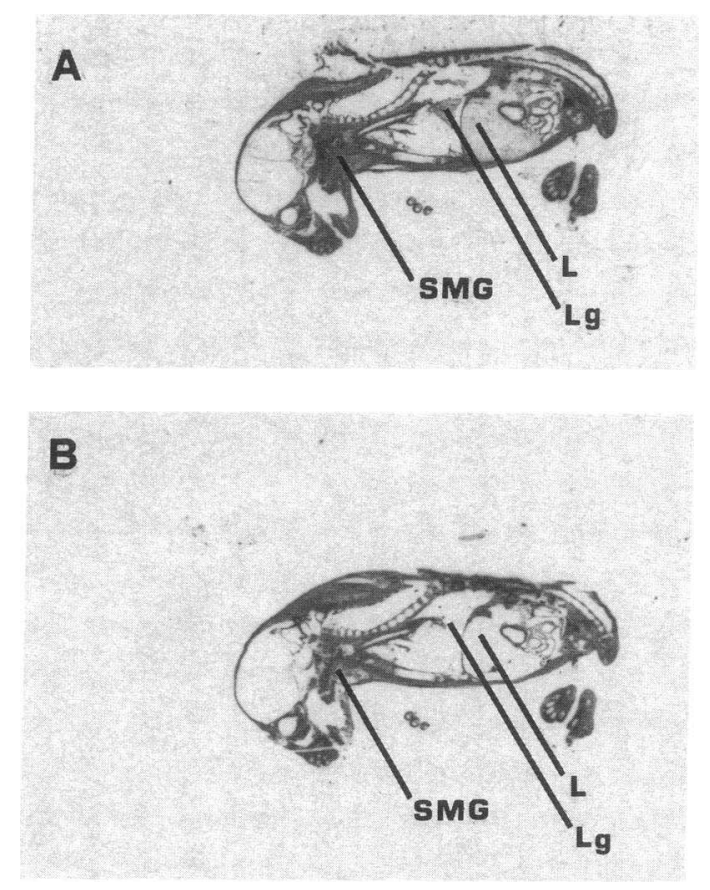

Figure 4. $\mathrm{AT}_{1}$ angiotensin II receptors in the rat fetus at E19. Autoradiography performed on frozen sections of an E19 rat fetus shows the distribution of radioligand binding to angiotensin II receptors (panel $A$ ). Diminution in $\mathrm{AT}_{1}$ receptor binding is found in the liver $(L)$, submaxillary gland $(S M G)$, and lung $(L g)$ after competition with DuP $753\left(10^{-5} \mathrm{M}\right)($ panel $B)(\times 1.5)$. 

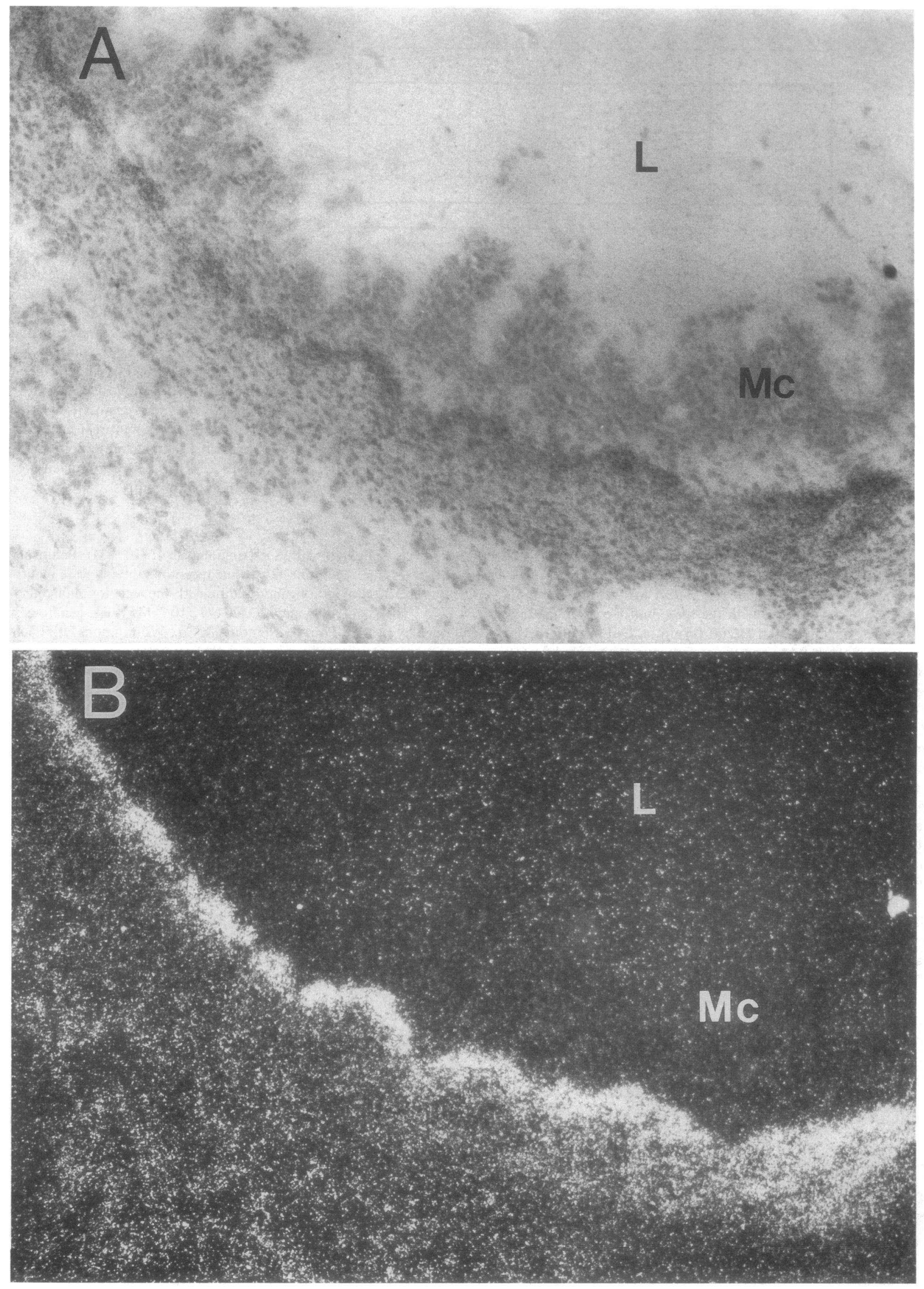

Figure 5. Bright-field (panels $A, C$, and $E$ ) and dark-field (panels $B, D$, and $F$ ) photomicrographs of angiotensin II radioligand binding visualized using emulsion autoradiography. Radioligand binding to angiotensin receptors in the fetal and neonatal sagittal sections was visualized by silver grains overlying cells expressing angiotensin II receptors. Abundant $\mathrm{AT}_{2}$ receptors are identified in the intestine (panels $A$ and $B ; L$, lumen; $M c$, mucosa), choroid surrounding the retina (panels $C$ and $D ; R$, retina; $C h$, choroid) and tongue (panels $E$ and $F$; $T$, tongue; $G$, gustatory papillae, $U$, upper palate) $(\times 687)$. 

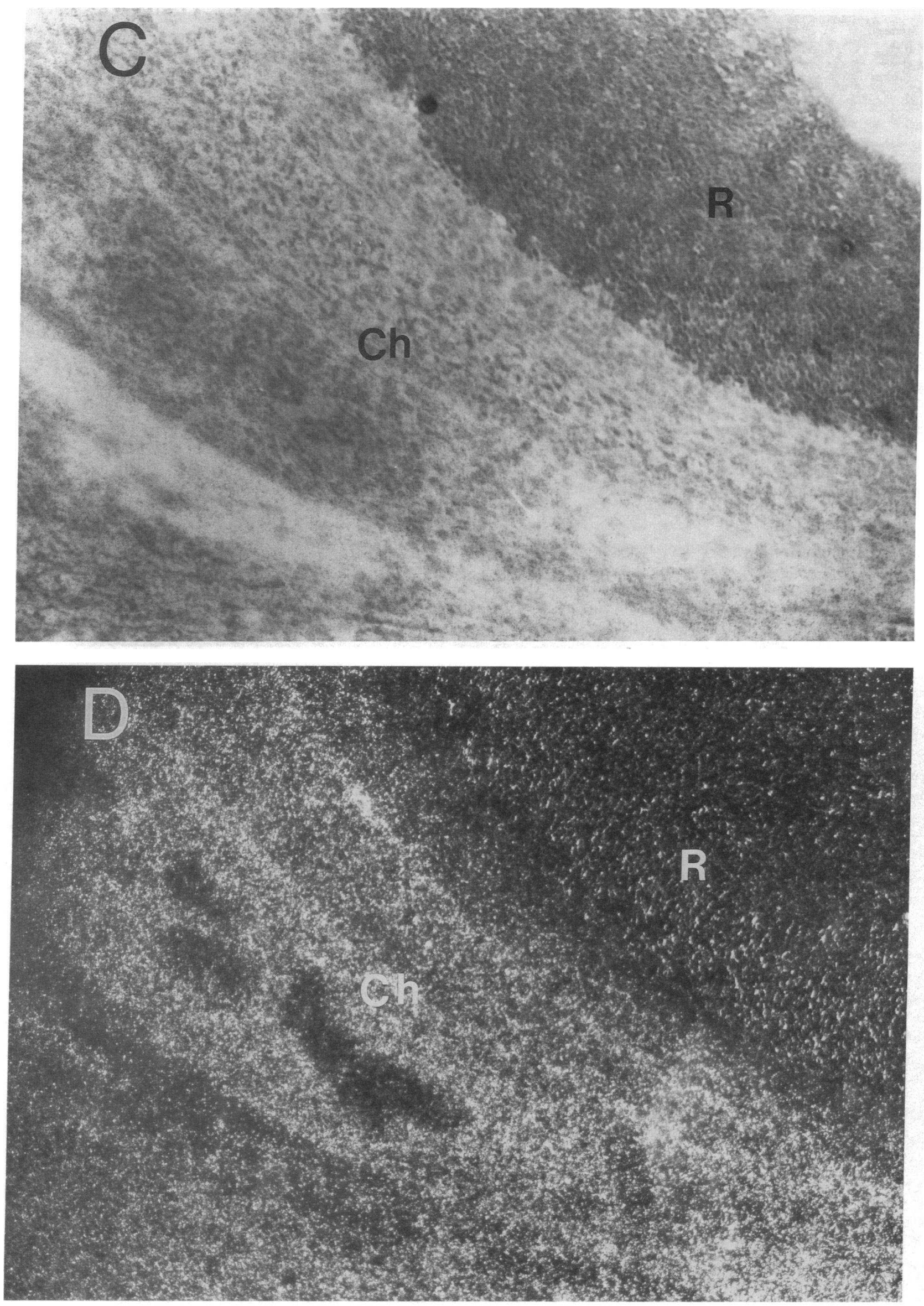

Figure 5 (Continued) 

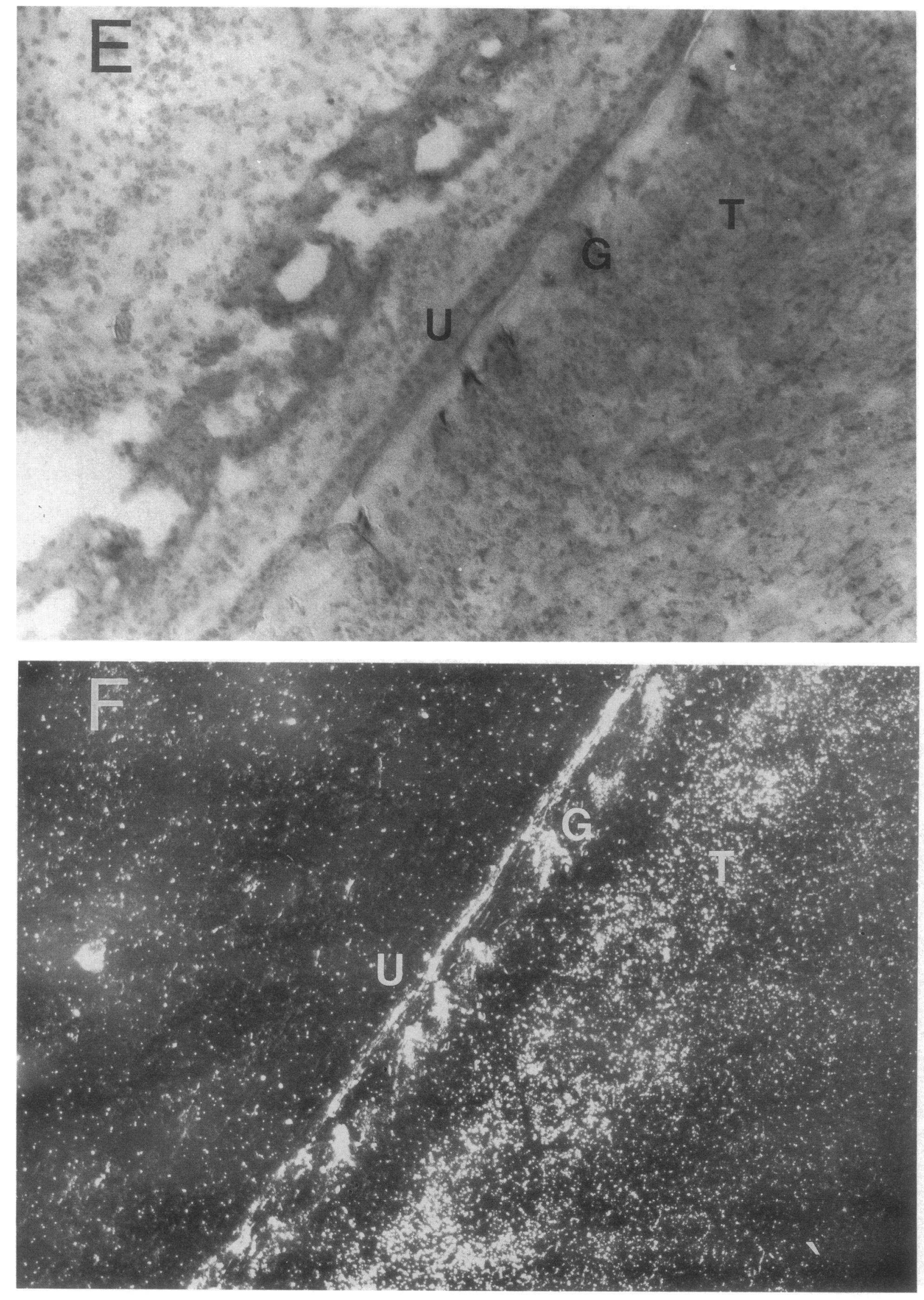

Figure 5 (Continued) 


\section{Results}

Developmental regulation of angiotensin II receptors. Autoradiographic visualization of radioligand binding to angiotensin II receptors was evident along the spine of the E14 fetus as depicted in Fig. 1 (top panel), but with longer exposures, angiotensin II receptors could also be detected at E11 (data not shown). Binding increased markedly by E16, was maximal by E19-21, and remained unaltered $30 \mathrm{~min}$ postparturition. Thereafter, radioligand binding decreased markedly by $12 \mathrm{~h}$ after birth and reached a stable nadir from 24 to 72 h (Fig. 1, top panel).

Using fetal sections obtained at E16, the specificity of radioligand binding was demonstrated by the ability of unlabeled [Sar ${ }^{1}$ ]-angiotensin II to compete for the majority of angiotensin II receptors at concentrations of $10^{-8} \mathrm{M}$ or greater (Fig. 2, top panel). This result correlates well with the known binding affinity of angiotensin II for its receptor. As also shown, radioligand binding was markedly reduced with PD123177 $\left(10^{-7} \mathrm{M}\right)$ (Fig. 2, middle panel), while substantially higher concentrations of DuP $753\left(10^{-4} \mathrm{M}\right)$ were necessary to achieve any binding inhibition (Fig. 2, bottom panel). These results indicate that the vast majority of the fetal angiotensin II receptors present at E16 are $\mathrm{AT}_{2}$. Radioligand binding at other fetal (E14, 16, and 19) and neonatal ( 0.5 and $24 \mathrm{~h})$ stages was eliminated with [Sar ${ }^{1}$ ]-angiotensin II $\left(10^{-5} \mathrm{M}\right)$ and PD123177 $\left(10^{-6} \mathrm{M}\right)$, while DuP $753\left(10^{-5} \mathrm{M}\right)$ had little effect (Fig. 1). These results demonstrate that the angiotensin II binding is specific and that throughout fetal development, the highly abundant receptors are $\mathrm{AT}_{2}$. Residual radioligand was found at all ages after competition with PD123177 and at $24 \mathrm{~h}$ after competition with either DuP 753 or PD123177 (Fig. 1). Combined competition with PD123177 and DuP 753 did not decrease the autoradiographic signal further (data not shown). In the neonatal animal, abundant radioligand binding to $\mathrm{AT}_{2}$ receptors remained on the dorsal surface of the tongue and mesenchyme surrounding the mandible as late as $72 \mathrm{~h}$ after birth (Fig. 3).

With longer exposure of sections obtained at E19, radioligand binding could be seen within the liver, lung, and submaxillary gland (Fig. $4 \mathrm{~A}$ ) that was eliminated with DuP 753 (Fig. 4 $B)$. Additional sites of $\mathrm{AT}_{1}$ receptor binding included the adrenal cortex, aorta, and kidney (data not shown). This indicates that $\mathrm{AT}_{1}$ receptors are present in the fetus with a tissue distribution identical to that found in the adult animal. Radioligand binding to $\mathrm{AT}_{2}$ receptors was also found in the placenta of E13 fetuses.

Cellular localization of $\mathrm{AT}_{2}$ angiotensin II receptors. Using emulsion autoradiography, abundant silver grains, indicative of bound radioligand, were evident by both bright (Fig. 5, $A, C$, and $E$ ) and dark-field (Fig. 5, $B, D$, and $F$ ) microscopy. The greatest number of grains were found overlying undifferentiated mesenchyme in the submucosal layers of the intestine (panels $A$ and $B ; L$, lumen; $M c$, mucosa) and stomach, connective tissue and choroid surrounding the retina (panels $C$ and $D$; $R$, retina; $C h$, choroid), dorsal subdermal region of the tongue (panels $E$ and $F ; T$, tongue; $G$, gustatory papillae; $U$, upper palate), and subdermal mesenchyme adjacent to developing cartilage, adrenal medulla, and diaphragm (data not shown). Fewer silver grains were found overlying well differentiated skeletal muscle while none were detected overlying bone. Radioligand binding was competed with the following antago- nists: [Sar ${ }^{1}$ ]-angiotensin II $\left(10^{-5} \mathrm{M}\right), \operatorname{PD} 123177\left(10^{-6} \mathrm{M}\right)$, and DuP $753\left(10^{-5} \mathrm{M}\right)$ (Fig. 6). Highly abundant silver grains were found overlying the intestinal mucosa (Fig. 6, $A$ and $B$ ) in sections incubated with radioligand alone. These silver grains were diminished drastically by both [Sar ${ }^{1}$ ]-angiotensin II (Fig. 6, $C$ and $D$ ) and PD123177 (Fig. 6, $E$ and $F$ ). Competition with DuP 753 had no effect on the levels of silver grains (Fig. 6, $G$ and $H$ ). These data confirm the specificity of the emulsion chemography.

\section{Discussion}

Highly abundant angiotensin II receptors were detected along the spine of the E11 rat fetus. This developmental expression agrees with membrane binding studies in which angiotensin II receptors were identified at about E10 (28). At this stage of development, the fetus is coiled in a C-shape, major organs are completing organogenesis, and the neural groove is open (39). By E14-16, when angiotensin II radioligand binding was easily detected, organogenesis is complete except for the urogenital tract, and the first skeletal cartilage appears in the ribs. The maximal radioligand binding that occurred at E19-20 correlates with ongoing mesenchyme differentiation into bone, vascular structures, muscle, and fat (39). $30 \mathrm{~min}$ after birth, receptors were still abundant in the mesenchyme, declining sharply thereafter and by $72 \mathrm{~h}$, persisted only in the subdermal layer of the tongue.

That the highly abundant receptors in the rat fetus are $\mathrm{AT}_{2}$ was demonstrated by the ability of PD123177, an $\mathrm{AT}_{2}$ receptor antagonist, to effectively eliminate radioligand binding. These $\mathrm{AT}_{2}$ angiotensin receptors were most abundant in the cells localized in the mesenchyme (Fig. 5). These cells have the potential to differentiate into smooth and striated muscle, connective tissue sheaths surrounding the muscle, blood vessels, and ligaments, and other cells such as chondroblasts, osteoblasts, and fibroblasts. The mesenchyme also induces regional epithelial differentiation as exemplified by the role palatal mesenchyme plays in inducing mandibular epithelium to differentiate in a palatal pattern (40). In addition, mesenchyme can itself be modified by the juxtaposed epithelium. For example, 1-d old murine uterine mesenchyme develops increased amounts of well organized myometrium only when it is grown with uterine epithelium (41). It is likely that the complex developmental decisions made by the multipotent mesenchymal cells are influenced by many environmental factors acting in sequence. Therefore, it is relevant that receptors for insulin-like growth factor I (42) and progesterone (43), and insulin-like growth factor I mRNA (42) are present in the mesenchyme of the fetus in a pattern similar to that of the angiotensin II receptor. In contrast, transforming growth factor (TGF) $\beta$ mRNA and protein has been localized to the mesenchyme during murine embryogenesis (44). This growth factor is thought to be coupled to mesenchymal remodeling involved in limb and digit formation and may be important in stimulating angiogenic activity. The $\mathrm{AT}_{2}$ receptors are localized to subdermal mesenchyme whereas TGF- $\beta$ is localized more to the mesenchymal cells in the dermis and epidermis (44). Serial section analysis will be necessary to determine accurately their comparative cellular localization. Even if $\mathrm{AT}_{2}$ receptors do not colocalize with TGF- $\beta$, the known reciprocal inductive influence epithelium and mesenchyme have on each other during devel- 

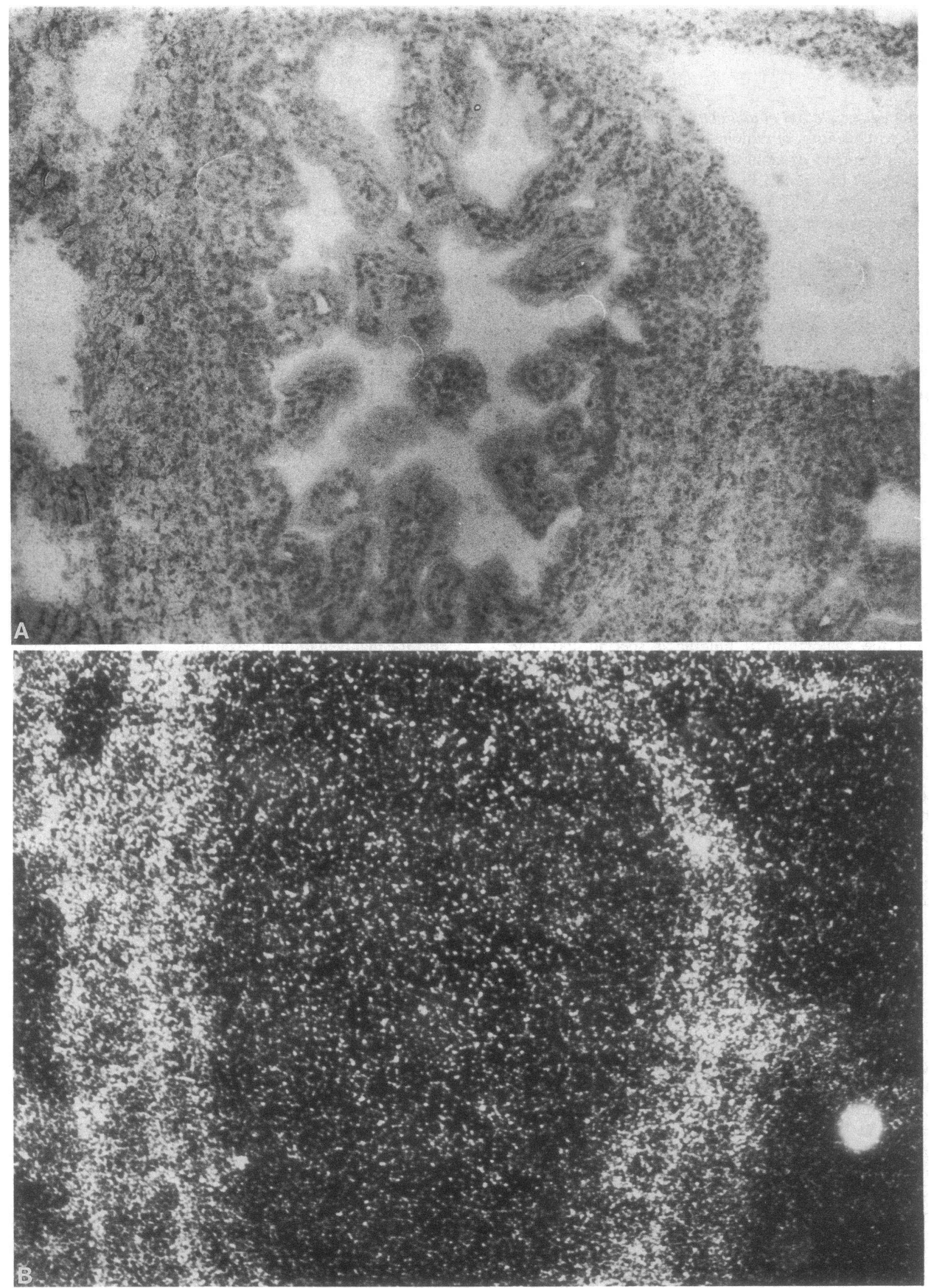

Figure 6. Bright-field (panels $A, C, E$, and $G$ ) and dark-field (panels $B, D, F$, and $H$ ) photomicrographs demonstrating the specificity of angiotensin II radioligand binding visualized using emulsion autoradiography. Radioligand binding to angiotensin receptors in $1 / 2$-h postnatal intestine was visualized by silver grains overlying cells expressing angiotensin II receptors (panels $A$ and $B$ ). Competition of radioligand binding with either [Sar'] ${ }^{1}$-angiotensin II (panels $C$ and $D$ ) or PD123177 (panels $E$ and $F$ ) dramatically diminished the number of silver grains to background levels. In contrast, DuP 753 (panels $G$ and $H$ ) had no significant effect on the number or distribution of silver grains $(\times 687)$. 

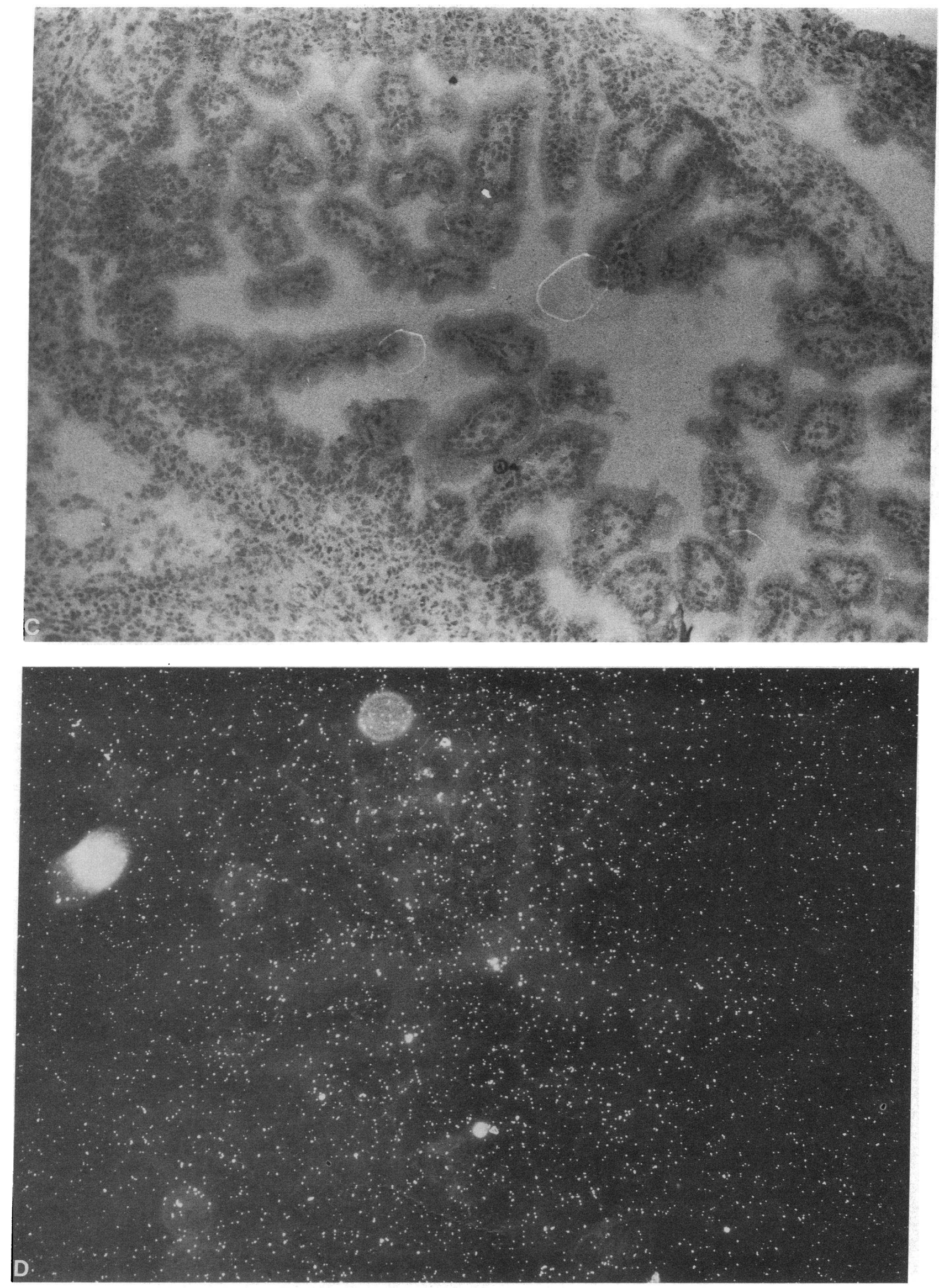

Figure 6 (Continued) 

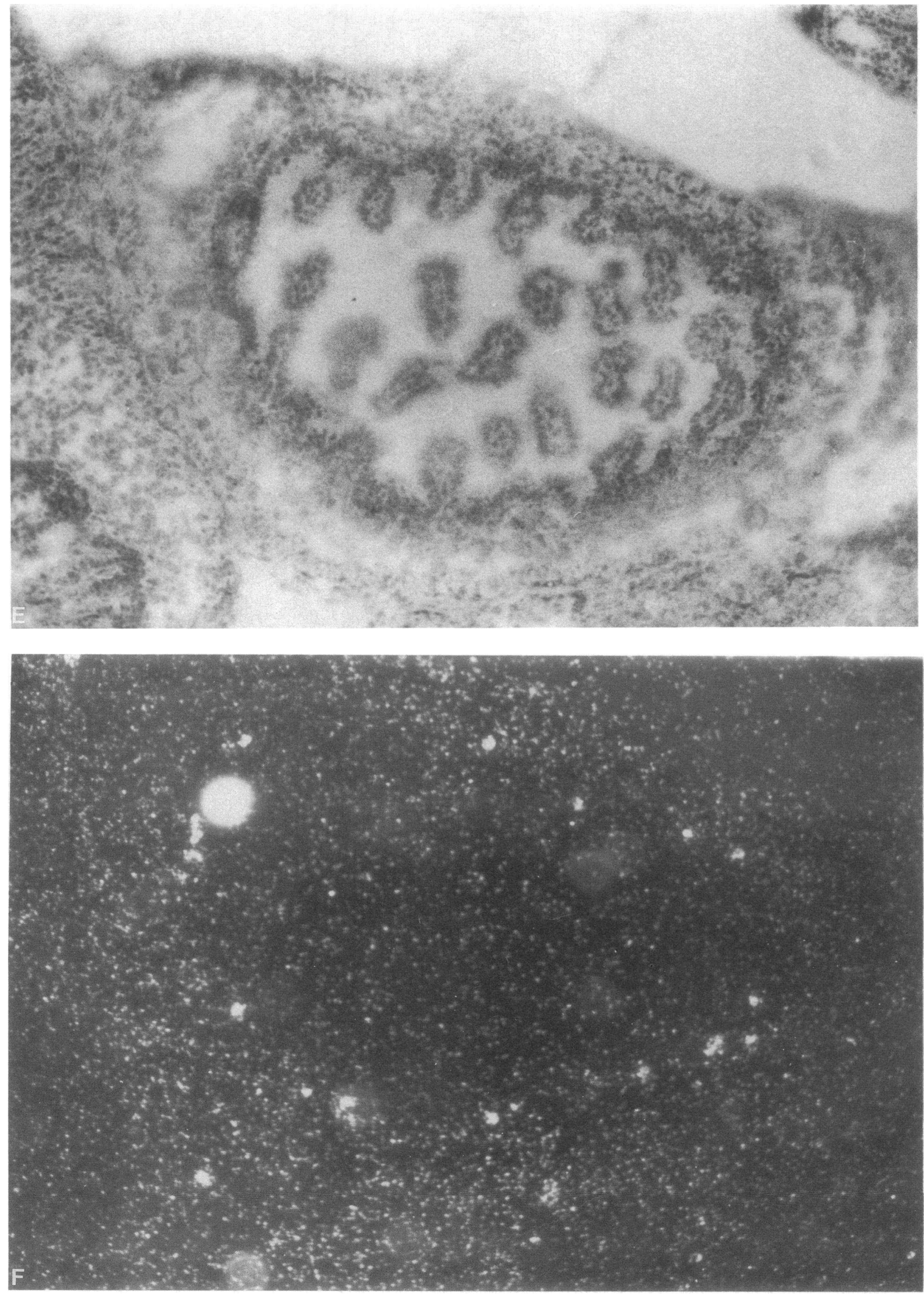

Figure 6 (Continued) 

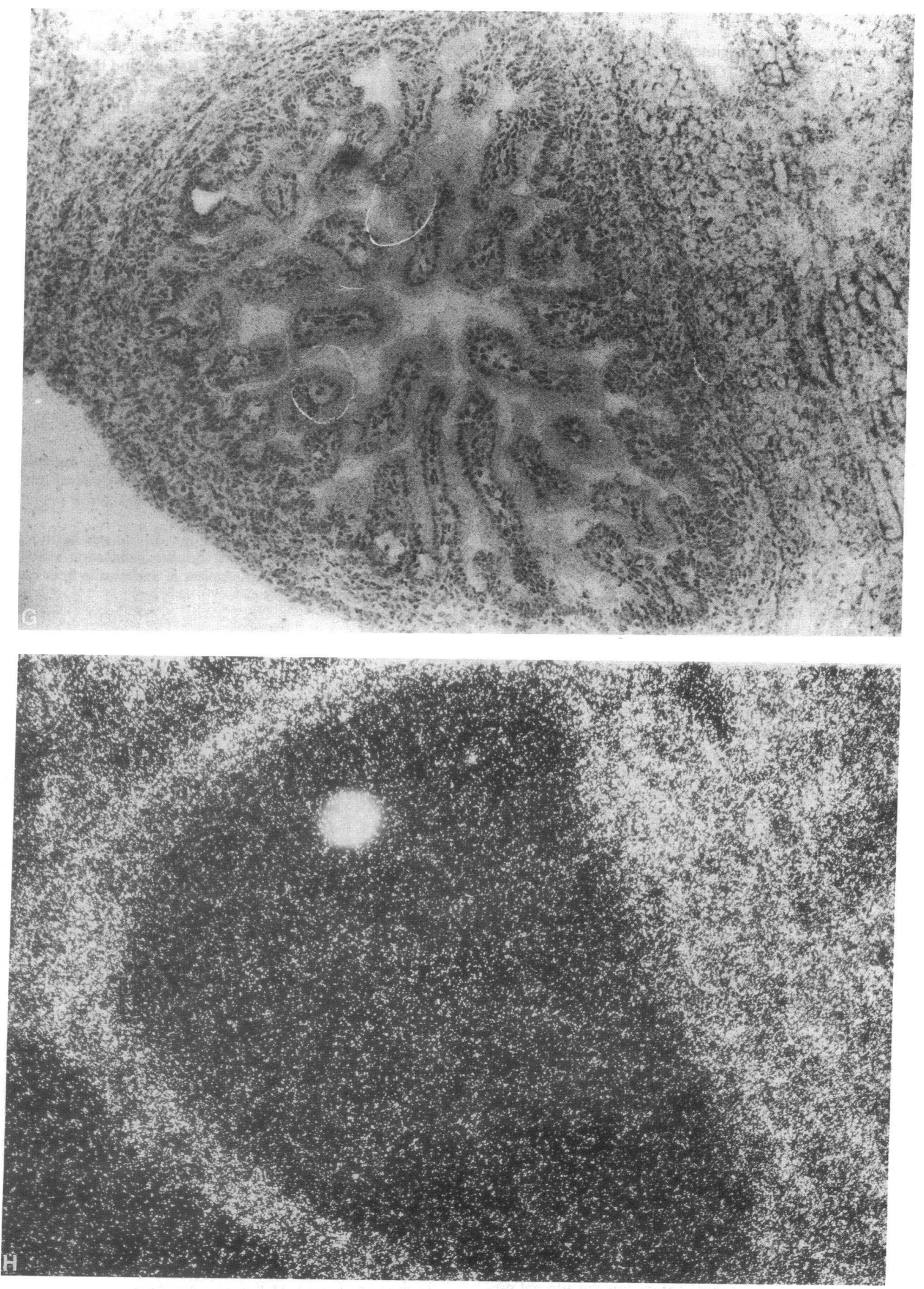

Figure 6 (Continued) 
opment makes it possible that angiotensin II may be modulating the synthesis or actions of TGF- $\beta$. Our finding of highly abundant $\mathrm{AT}_{2}$ receptors on the less differentiated mesenchymal cells of the rat fetus also suggests that angiotensin II may have a role in mesenchymal regeneration, differentiation, and/ or as a potentiator of other growth factors.

Our findings indicate that the majority of the angiotensin II receptors expressed in the mesenchyme of the developing rat embryo are $\mathrm{AT}_{2}$. It is also evident with both film and emulsion autoradiography that residual, albeit low levels, of radioligand binding remain after PD123177 competition. Combined DuP $753\left(10^{-5} \mathrm{M}\right)$ and PD123177 $\left(10^{-6} \mathrm{M}\right)$ was equally ineffective in eliminating this residual binding. These data suggest, although do not prove, that a third angiotensin II receptor subtype may be present. Further studies will be necessary to investigate this possibility.

The presence of a receptor is functionally unimportant if its ligand is not present. Therefore it is important to note that all the components of the RAS have been found in the developing fetal-placental unit $(45,46)$. Renin and angiotensin converting enzyme have been detected in the second third of gestation (47-50). Lee et al. (51) detected angiotensinogen mRNA in the body of the rat embryo as early as day 9 with mRNA levels reaching a maximum by day 15 . Day 15 is when the $A_{2}$ receptors become easily detected, but they do not reach their maximum until day 19-21. Whether the increased synthesis of either angiotensinogen or angiotensin II is the stimulus for greater $\mathrm{AT}_{2}$ receptor expression remains to be determined. Finally, angiotensin II has been isolated from and identified in the eviscerated rat fetus by using a combination of chromatographic elution and radioimmunoassay and displacement of radioligand binding from adrenal membranes (28).

Numerous studies indicate that angiotensin II plays a role in the regulation of cell growth. Angiotensin II increases protein synthesis, content, and cell size in murine proximal tubule cells (52) and augments epidermal growth factor-induced proliferation (21). In vitro, angiotensin II induces similar increases in protein synthesis and hypertrophy of vascular smooth muscle cells (53). In addition, angiotensin converting enzyme inhibitors, which decrease circulating angiotensin II levels, suppress the proliferative response of rat vascular smooth muscle cells to injury, again suggesting that angiotensin potentiates a growth response (54). Finally, the treatment of vascular smooth muscle cells with angiotensin II increases expression of c-fos (23, 24) and c-myc (22), platelet-derived growth factor A chain (22), thrombosporin (55), and TGF- $\beta$ mRNAs (55). These growth factors have all been shown to be upregulated in early stages of cell growth.

In contrast to the $\mathrm{AT}_{2}$ receptor which predominates in the mesenchyme of the fetus and is only found in the adrenal medulla (32), uterus (30), a subset of brain nuclei, $(56,57)$ and ovary (58) of the adult animal, the $\mathrm{AT}_{1}$ receptor is more abundant and widespread in the mature animal. In fact, the majority of the cardiovascular and hormone modulating actions of angiotensin II in the adult animal are mediated through the $\mathrm{AT}_{1}$ receptor (33-35). Longer autoradiographic exposure of the E19 fetal sections showed that there was specific, although lower, levels of radioligand binding to the following organs: liver, lung, submaxillary gland, adrenal cortex and medulla, and kidney. DuP 753, an $\mathrm{AT}_{1}$ receptor antagonist, eliminated radioligand binding in all of these organs but the adrenal medulla. This demonstrates that these receptors are $\mathrm{AT}_{1}$ and are present in the fetus with a tissue distribution identical to that found in the adult animal $(32,59-61)$. Radioligand binding to $\mathrm{AT}_{1}$ receptors was also found in the placenta of the E13 fetuses where they are thought to function in modulating placental circulation (45).

The cellular and biochemical mechanisms involved in embryogenesis are complex and a variety of polypeptides appear to be necessary to regulate cell growth, differentiation, and functional maturation. In addition, it has been proposed that some of the mechanisms involved in embryogenesis may be reiterated in the adult, functioning in tissue repair, angiogenesis, or as a factor involved in carcinogenesis. The presence of angiotensin II during fetal development in conjunction with the transient expression of the $\mathrm{AT}_{2}$ receptor in the developing rat fetus, suggests to us that angiotensin II, acting through the $\mathrm{AT}_{2}$ receptor, may be one of the peptide hormones involved in fetal development.

\section{Acknowledgments}

We would like to thank Dr. E. Howes and Dr. G. Cunha for their helpful discussions, Dr. R. Pitas for the use of his equipment, Lin Moses for her secretarial support, and Carolyn Breaux for her photographic assistance.

This research was supported by grants from the National Institutes of Health (HL-11046) and National Science Foundation (BNS9012025). Leonardo A. Sechi is a recipient of a fellowship from the Italian Society of Hypertension.

\section{References}

1. Glossman, H., A. Baukal, G. Aguilera, and K. J. Catt. 1985. Radioligand assay for angiotensin II receptors. Methods Enzymol. 109:110-126.

2. Aguilera, G., M. A. Millan, and J. P. Harwood. 1989. Angiotensin II receptors in the gonads. Am. J. Hypertens. 2:395-402.

3. Allen, A. M., H. Yamada, and F. A. O. Mendelsohn. 1990. In vitro autoradiographic localization of binding to angiotensin receptors in the rat heart. Int. J. Cardiol. 28:25-33.

4. Oparil, S., and E. Haber. 1974. The renin-angiotensin system (first of two parts). N. Engl. J. Med. 291:389-401.

5. Wright, F. S., and J. P. Briggs. 1979. Feedback control of glomerular blood flow, pressure, and filtration rate. Physiol. Rev. 59:958-1006.

6. Steele, M. K., A. Negro-Vilar, and S. M. McCann. 1981. Effect of angiotensin II on in vivo and in vitro release of anterior pituitary hormones in the female rat. Endocrinology. 109:893-899.

7. Ames, R. P., A. J. Borkowski, A. M. Sicinski, and J. H. Laragh. 1965. Prolonged infusions of angiotensin II and norepinephrine and blood pressure, electrolyte balance, and aldosterone and cortisol secretion in normal man and in cirrhosis with ascites. J. Clin. Invest. 44:1171-1186.

8. Ramsay, D. J., L. C. Keil, M. C. Sharpe, and J. Shinsako. 1978. Angiotensin II infusion increases vasopressin, ACTH, and 11-hydroxycorticosteroid secretion. Am. J. Physiol. 234:R66-R71.

9. Rivier, C., and W. Vale. 1983. Effect of angiotensin II on ACTH release in vivo: role of corticotropin-releasing factor. Regul. Pept. 7:253-258.

10. Phillips, I. M. 1987. Functions of angiotensin in the central nervous system. Annu. Rev. Physiol. 49:413-435.

11. Lightman, A., C. L. Jones, N. J. MacLusky, A. Palumbo, A. H. Decherney, and F. Naftolin. 1988. Immunocytochemical localization of angiotensin II immunoreactivity and demonstration of angiotensin II binding in the rat ovary. Am. J. Obstet. Gynecol. 159:526-530.

12. Pellicer, A., A. Palumbo, A. H. Decherney, and F. Naftolin. 1988. Blockage of ovulation by an angiotensin antagonist. Science (Wash. DC). 240:16601661.

13. Ohkubo, H., K. Nakayama, T. Tanaka, and S. Nakanishi. 1986. Tissue distribution of rat angiotensinogen mRNA and structural analysis of its heterogeneity. J. Biol. Chem. 261:319-323.

14. Campbell, D. J., and J. F. Habener. 1986. Angiotensinogen gene is expressed and differentially regulated in multiple tissues of the rat. J. Clin. Invest. 78:31-39.

15. Pipkin, F. B., and E. M. Symonds. 1984. Renin-angiotensin system in early life. In Fetal Physiology and Medicine. The Basis of Perinatology. R. W. 
Beard and P. W. Nathanielsz, editors. Marcel Dekker, New York. 459-480.

16. Ghiani, P., B. M. Uva, A. Mandich, and M. A. Masini. 1988. Angiotensin II vascular receptors in fetal and neonatal rats. Cell Biochem. Funct. 6:283-287.

17. Kalinyak, J. E., and A. J. Perlman. 1987. Tissue-specific regulation of angiotensin mRNA accumulation by dexamethasone. J. Biol. Chem. 262:460 464.

8. Mendelsohn, F. A. O., G. Aguilera, J. M. Saavedra, R. Quirion, and K. J. Catt. 1983. Characteristics and regulation of angiotensin II receptors in pituitary, circumventricular organs and kidney. Clin. Exp. Hypertens. Part A Theory Pract. A5(7\&8):1081-1097.

19. Wilkes, B. M., I. Pion, S. Sollott, S. Michaels, and G. Kiesel. 1988. Intrarenal renin-angiotensin system modulates glomerular angiotensin receptors in the rat. Am. J. Physiol. 254:F345-F350.

20. Schelling, P., H. Fischer, and D. Ganten. 1991. Angiotensin and cell growth: a link to cardiovascular hypertrophy?. J. Hypertens. 9:3-15.

21. Norman, J., B. Badie-Dezfooly, E. P. Nord, I. Kurtz, J. Schlosser, A. Chaudhari, and L. G. Fine. 1987. EGF-induced mitogenesis in proximal tubular cells: potentiation by angiotensin II. Am. J. Physiol. 253:F299-F309.

22. Naftilan, A. J., R. E. Pratt, and V. J. Dzau. 1989. Induction of platelet-derived growth factor A-chain and c-myc gene expressions by angiotensin II in cultured rat vascular smooth muscle cells. J. Clin. Invest. 83:1419-1424.

23. Kawahara, Y., M. Sunako, T. Tsuda, H. Fukuzaki, Y. Fukomoto, and Y. Takai. 1988. Angiotensin II induces expression of the c-fos gene through protein kinase $\mathrm{C}$ activation and calcium ion mobilization. Biochem. Biophys. Res. Commun. 150:52-59.

24. Taubman, M. B., B. C. Berk, S. Izumo, T. Tsuda, R. W. Alexander, and B. Nadal-Ginard. 1989. Angiotensin II induces c-fos mRNA in aortic smooth muscle. J. Biol. Chem. 264:526-530.

25. Naftilan, A. J., G. K. Gilliland, C. S. Eldridge, and A. S. Kraft. 1990 Induction of the proto-oncogene c-jun by angiotensin II. Mol. Cell. Biol. 10:5536-5540.

26. Millan, M. A., P. Carvallo, S.-I. Izumi, S. Zemel, K. J. Catt, and G. Aguilera. 1989. Novel sites of expression of functional angiotensin II receptors in the late gestation fetus. Science (Wash. DC). 244:1340-1342.

27. Zemel, S., M. A. Millan, and G. Aguilera. 1989. Distribution of angiotensin II receptors and renin in the mouse fetus. Endocrinology. 124:1774-1780.

28. Jones, C., M. A. Millan, F. Naftolin, and G. Aguilera. 1989. Characterization of angiotensin II receptors in the rat fetus. Peptides (Elmsford). 10:459-463.

29. Zemel, S., M. A. Millan, P. Feuillan, and G. Aguilera. 1990. Characterization and distribution of angiotensin-II receptors in the primate fetus. J. Clin. Endocrinol. Metab. 71:1003-1007.

30. Whitebread, S., M. Mele, B. Kamber, and M. de Gasparo. 1989. Preliminary biochemical characterization of two angiotensin II receptor subtypes. Bio chem. Biophys. Res. Commun. 163:284-291.

31. Chiu, A. T., D. E. McCall, T. T. Nguyen, D. J. Carini, J. V. Duncia, W. F Herblin, R. T. Uyeda, P. C. Wong, R. R. Wexler, A. L. Johnson, and P. B. M. W. M. Timmermans. 1989. Discrimination of angiotensin II receptor subtypes by dithiothreitol. Eur. J. Pharmacol. 170:117-118.

32. Chiu, A. T., W. F. Herblin, D. E. McCall, R. J. Ardecky, D. J. Carini, J. V. Duncia, L. J. Pease, P. C. Wong, R. R. Wexler, A. L. Johnson, and P. B. M. W. M. Timmermans. 1989. Identification of angiotensin II receptor subtypes. Biochem. Biophys. Res. Commun. 165:196-203.

33. Wong, P. C., W. A. Price, A. T. Chiu, J. V. Duncia, D. J. Carini, R. R. Wexler, A. L. Johnson, and P. B. M. W. M. Timmermans. 1990. Nonpeptide angiotensin II receptor antagonists. VIII. Characterization of functional antagonism displayed by DuP 753, an orally active antihypertensive agent. J. Pharmacol. Exp. Ther. 252:719-725.

34. Wong, P. C., W. A. Price, A. T. Chiu, J. V. Duncia, D. J. Carini, R R. Wexler, A. L. Johnson, and P. B. W. M. Timmermans. 1989. Nonpeptide angiotensin II receptor antagonists. IX. Antihypertensive activity in rats DuP 753, an orally active antihypertensive. $J$. Pharmacol. Exp. Ther. 252:726-732.

35. Wong, P. C., S. D. Hart, A. M. Zaspel, A. T. Chiu, R. J. Ardecky, R. D. Smith, and P. B. M. W. M. Timmermans. 1990. Functional studies of nonpeptide angiotensin II receptor subtype-specific ligands: DuP 753 (AII-1) and PD123177 (AII-2). J. Pharmacol. Exp. Ther. 255:584-592.

36. Mendelsohn, F. A. O., R. Quirion, J. M. Saavedra, G. Aguilera, and K. J. Catt. 1984. Autoradiographic localization of angiotensin II receptors in rat brain. Proc. Natl. Acad. Sci. USA. 81:1575-1579.

37. Mendelsohn, F. A. O., M. Millan, R. Quirion, G. Aguilera, S.-T. Chou, and K. J. Catt. 1987. Localization of angiotensin II receptors in rat and monkey kidney by in vitro autoradiography. Kidney Int. 31:S40-S44.

38. Herkenham, M., and C. B. Pert. 1982. Light microscopic localization of brain opiate receptors: a general autoradiographic method which preserves tissue quality. $J$. Neurosci. 2:1129-1149.
39. Beaudoin, A. R. 1980. Embryology and teratology. In The Laboratory Rat. Vol. II. Research Applications. H. J. Baker, J. R. Lindsey, and S. H. Weis broth, editors. Academic Press, New York. 75-101.

40. Ferguson, M. W. J., and L. S. Honig. 1984. Epithelial-mesenchymal interactions during vertebrate palatogenesis. In Current Topics in Developmenta Biology. A. A. Moscona and A. Monroy, editors. Academic Press, New York 137-164.

41. Cunha, G. R., P. Young, and J. R. Brody. 1989. Role of uterine epithelium in the development of myometrial smooth muscle cells. Biol. Reprod. 40:861871.

42. Bondy, C. A., H. Werner, C. T. Roberts, Jr., and D. LeRoith. 1990 Cellular pattern of insulin-like growth factor-I (IGF-I) and Type I IGF receptor gene expression in early organogenesis: comparison with IGF-II gene expression. Mol. Endocrinol. 4:1386-1398.

43. Shughrue, P. J., W. E. Stumpf, and M. Sar. 1988. The distribution of progesterone receptor in the 20-day-old fetal mouse: an autoradiographic study with [125I]progestin. Endocrinology. 123:2382-2389.

44. Heine, U. I., E. F. Munoz, K. C. Flanders, L. R. Ellingsworth, H.-Y. P. Lam, N. L. Thompson, A. B. Roberts, and M. B. Sporn. 1987. Role of transforming growth factor-beta in the development of the mouse embryo. J. Cell Biol. 105:2861-2876.

45. Wilkes, B. M., E. Krin, and P. F. Mento. 1985. Evidence for a functional renin-angiotensin system in full-term fetoplacental unit. Am. J. Physiol. 249:E366-E373.

46. Gomez, R. A., L. Cassis, K. R. Lynch, R. L. Chevalier, N. Wilfong, R. M. Carey, and M. J. Peach. 1988. Fetal expression of the angiotensinogen gene. Endocrinology. 123:2298-2302.

47. Richoux, J. P., S. Amsaguine, G. Grignon, J. Bouhnik, J. Menard, and P. Corvol. 1987. Earliest renin containing cell differentiation during ontogenesis in the rat. Histochemistry. 88:41-46.

48. Wigger, H. J., and S. A. Stalcup. 1978. Distribution and development of angiotensin converting enzyme in the fetal and newborn rabbit. An immunofluorescence study. Lab. Invest. 38:581-585.

49. Wallace, K. B., M. D. Bailie, and J. B. Hook. 1979. Development of angiotensin-converting enzyme in fetal rat lungs. Am. J. Physiol. 236:R57-R60.

50. Taylor, G. M., W. S. Peart, K. A. Porter, L. H. Zondek, and T. Zondek. 1986. Concentration and molecular forms of active and inactive renin in human fetal kidney, amniotic fluid and adrenal gland: evidence for renin-angiotensin system hyperactivity in 2nd trimester of pregnancy. J. Hypertens. 4:121-129.

51. Lee, H. U., D. J. Campbell, and J. F. Habener. 1987. Developmental expression of the angiotensinogen gene in rat embryos. Endocrinology. 121:1335-1342.

52. Wolf, G., and E. G. Neilson. 1990. Angiotensin II induces cellular hypertrophy in cultured murine proximal tubular cells. Am. J. Physiol. 259:F768F777.

53. Geisterfer, A. A. T., M. J. Peach, and G. K. Owens. 1988. Angiotensin II induces hypertrophy, not hyperplasia, of cultured rat aortic smooth muscle cells. Circ. Res. 62:749-756.

54. Powell, J. S., J. -P. Clozel, R. K. M. Muller, H. Kuhn, F. Hefti, M. Hosang, and H. R. Baumgartner. 1989. Inhibitors of angiotensin-converting enzyme prevent myointimal proliferation after vascular injury. Science (Wash. DC). 245:186-188.

55. Powell, J. S., M. Rouge, R. K. M. Muller, H. R. Baumgartner, and F. Hoffman. 1990. The proliferative response to vascular injury: the role of angiotensin II induction of PDGF and thrombospondin. In Growth Factors in Health and Disease. B. Westermark, C. Betsholtz, and B. Hokfelt, editors. Elvevier Science Publishers B. V., Amsterdam. 117-129.

56. Chang, R. S. L., V. J. Lotti, T. B. Chen, and K. A. Faust. 1990. Two angiotensin II binding sites in rat brain revealed using [125I]sar1,ILE8-angiotensin II and selective nonpeptide antagonists. Biochem. Biophys. Res. Commun. 171:813-817.

57. Rowe, B. P., K. L. Grove, D. L. Saylor, and R. C. Speth. 1990. Angiotensin II receptor subtypes in the rat brain. Eur. J. Pharmacol. 186:339-342.

58. Pucell, A. G., J. C. Hodges, I. Sen, F. M. Bumpus, and A. Husain. 1991. Biochemical properties of the ovarian granulosa cell type 2-angiotensin II receptor. Endocrinology. 128:1947-1959.

59. Douglas, J. G. 1987. Angiotensin receptor subtypes of the kidney cortex Am. J. Physiol. 253:F1-F7.

60. Speth, R. C., and K. H. Kim. 1990. Discrimination of two angiotensin II receptor subtypes with a selective agonist analogue of angiotensin II, $p$-aminophenylalanine angiotensin II. Biochem. Biophys. Res. Commun. 169:997-1006.

61. Rogg, H., A. Schmid, and M. de Gasparo. 1990. Identification and characterization of angiotensin II receptor subtypes in rabbit ventricular myocardium. Biochem. Biophys. Res. Commun. 173:416-422. 